\title{
ニッケルージメチルグリオキシム錯体の固相抽出と その鋼中ニッケルの原子吸光定量への応用
}

\author{
小熊 幸一 $* * 2 \cdot$ 泉 陽誉* $*$ 櫻井 裕樹*2 - 野呂 純二 $* 2$
}

Solid-phase Extraction of Nickel Dimethylglyoximato Complex and Its Application to Determination of Nickel in

Steel by Atomic Absorption Spectrometry

Koichi Oguma, Takayasu IzUmi, Hiroki SAKurai and Junji Noro

\begin{abstract}
Synopsis : A solid-phase extraction method has been developed for the selective separation of nickel and applied to the determination of nickel in lead free-cutting steel. An appropriate amount of sample was dissolved in a mixture of hydrochloric acid, nitric acid, and hydrogen peroxide, and was finally prepared as a solution of $0.1 \mathrm{M}$ tartaric acid- $-0.05 \%$ dimethylglyoxime (DMG) $-0.05 \%$ Triton X-100 (pH 10). The sample solution was then passed through a column packed with polystyrene divinylbenzene copolymer resin to collect nickel as DMG complexes. Nickel complexes adsorbed on the column was eluted with $2 \mathrm{M}$ hydrochloric acid and the effluent was evaporated to dryness. The residue was dissolved in $0.1 \mathrm{M}$ hydrochloric acid and diluted to an appropriate volume with the same acid, followed by the determination of nickel by flame atomic absorption spectrometry. The present method was applied to the determination of nickel in a certified reference material JSS 519-1 (lead free-cutting steel, Japan Iron and Steel Federation) and $558 \pm 6 \mu \mathrm{g} \mathrm{g}^{-1}(n=3)$ was obtained (certified value: $560 \mu \mathrm{g} \mathrm{g}^{-1}$ ).
\end{abstract}

Key words : nickel; dimethlglyoxime; steel; solid-phase extraction; atomic absorption spectrometry.

\section{1. 緒言}

ニッケルは常温できわめて安定な金属であり, 鋼に添加 すると強勒性が著しく増加するため, 合金材料として重要 な役割を果たしている1)。近年, 資源有効活用の観点から, スクラップの利用が拡大しつつある。製鋼において，ニッ ケルが含まれるスクラップ鋼を用いる場合には，それらか ら供給される炉内溶鋼中のニッケル含量を知り，追加量を 決定するため迅速分析法が必要になってくる。おおよそ 1980年前後から，鉄鋼製造現場の分析では鉄鋼試料の 80 90\%が固体試料を対象とする発光分析法打よび蛍光 X 線分析法でモニターされている2)。

非破壊分析法である発光分析法と蛍光X線分析法は迅速 性において優れているが, 測定試料の大きさ, 形状, 表面 の仕上がりの影響を受けやすいこと, 検量線作成のために マトリックスマッチングした標準物質を必要とすること, などの難点を有する ${ }^{3)}$ 。一方, 溶液化した試料を対象とす る湿式化学分析法は, 迅速性には欠けるものの, 発光分析 法と蛍光X線分析法のもつ上記の問題が生じないため, 標 準的分析法として位置づけられるようになっている2)。す なわち, 発光分析法および䖝光X線分析法の分析值の信頼 性は, 湿式化学分析法により值付けされた標準物質を検量
線作成に用いることによって保証されている4)。このよう なことから, 例えば, $\mathrm{Ni}$ の選択的湿式化学分析法の開発 は，鉄鋼中に含まれる微量元素の正確な分析法の構築と いった観点から重要なものと認識されている。

従来, 鉄鋼中 $0.003 \sim 1.0 \%(\mathrm{~m} / \mathrm{m})$ の $\mathrm{Ni}$ は, 酸分解した試 料溶液をそのまま用いてフレーム原子吸光法(FAAS)によ り定量することができる5)。しかし，この方法で検量線を 作成する際, 正確な $\mathrm{Ni}$ 含有率が知られている高純度 $\mathrm{Fe} に$ よるマトリックスマッチングが不可欠である。一方, クエ ン酸を $\mathrm{Fe}(\mathrm{III})$ のマスキング骫に用いるジメチルグリオキシ ム $(\mathrm{DMG})$ 吸光光度法が JIS 規格6)に採用されている。しか しながら，Crを含む場合には二酸化二塩化クロムとして 揮散させて除去するために長時間を要し, 過塩素酸の取扱 いには注意が必要である。さらに, DMG は鉄鋼中の含有 量が $0.1 \%$ 以上の Niに対して, DMG 重量法打よびDMG沈 殿分離エチレンジアミン四酶酸二水素ナトリウム・亜鉛逆 滴定法に古くから利用されているの。

近年, 環境負荷が少ない分離法として固相抽出法》が注 目されているが, DMGを $\mathrm{Ni}(\mathrm{II})$ の固相抽出に用いた研究も 報告されている。Ali $ら^{8)}$ は, Ni(II)-DMG 錯体をフローイ ンジェクション分析システム内で形成させ，オクタデシル シリカのカラムに捕集し，硝酸を含むエタノールで溶離し

平成22年 4月 13 日受付 平成22年 7月 7日受理 (Received on Apr. 13, 2010; Accepted on July 7, 2010)

* 千葉大学大学院工学研究科 (Graduate School of Engineering, Chiba University, 1-33 Yayoi-cho Inage-ku Chiba 263-8522)

*2 (株) 日産アーク研究部 (Research Department, Nissan Analysis and Research Center) 
て直接FAASのネブライザーに導入することを試みてい る。この方法は, クエン酸ナトリウムを $\mathrm{Fe}(\mathrm{III})$ のマスキン グ棛に用いて NBS製特殊低合金鋼標準物質中の $\mathrm{Ni}$ の定量 に応用されている。しかしながら，エタノールの消費量が 多いのが難点である。一方, Shemirani ( $^{9}$ は，アルミナ粉 末とドデシル硫酸ナトリウムからなるアドミセルに DMG を固定化し，この表面修飾したアルミナを充てんしたカラ ムを $\mathrm{Ni}(\mathrm{II})$ の固相抽出に用いている。カラムに捕集された $\mathrm{Ni}(\mathrm{II})$ は，1 M 硝酸で溶離回収し FAAS で定量することがで きる。この方法はニッケルめっき液打よび水試料中の $\mathrm{Ni}$ の定量に応用されている。なお, Eichrom Technologies (Darien, IL)は，DMGをポリメタクリル酸樹脂に担持した

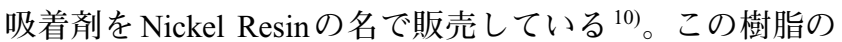
用途は，放射性 $\mathrm{Ni}$ 核種の選択的捕集である。我々は，こ の吸着剤を用いて $\mathrm{Fe}(\mathrm{III})$ と $\mathrm{Ni}(\mathrm{II})$ の相互分離を試みたとこ ろ， $\mathrm{Ni}(\mathrm{II})$ の樹脂への吸着は定量的であるものの，酸によ る定量的な溶離回収が不可能であることを見いだし，その 使用を断念した。

本研究では, $\mathrm{Ni}$ の高選択的分離法の開発を目的とし, 塩基性溶液において生成する $\mathrm{Ni}(\mathrm{II})-\mathrm{DMG}$ 錯体を疎水性樹 脂に捕集することを試みた。その結果，非イオン界面活性 剂Triton X-100の共存下で生成した $\mathrm{Ni}(\mathrm{II})-\mathrm{DMG}$ 錯体は疎水 性樹脂に定量的に吸着し, しかも希塩酸で定量的に溶離で きることを見いだした。さらに, 酒石酸を $\mathrm{Fe}(\mathrm{III})$ のマスキ ング剤として用いて鉄鋼中 $\mathrm{Ni}$ の分離法を確立し, FAAS と の併用により鉛快削鋼中 $\mathrm{Ni}$ の高精度定量を達成した。

\section{2. 実験}

\section{$2 \cdot 1$ 試薬}

固相抽出の吸着片として, ポリスチレンジビニルベンゼ ン共重合体である MCI-GEL CHP20P（粒径 37 75 $\mu \mathrm{m}$, 細 孔径 $45 \mathrm{~nm}$, 三菱化学, 以下 $\mathrm{CHP} 20 \mathrm{P}$ と略) を用いた。

試薬は, 市販特級品を使用した。水は蒸留後, イオン交 換樹脂で脱イオンし，Milli-Q ${ }^{\circledR}$ 超純水製造装置（日本ミリ ポア）により精製したものを使用した。

金属標準液 $\left(1000 \mu \mathrm{g} \mathrm{mL}^{-1}\right)$ は, 各金属の塩化物, 硝酸塩, あるいは硫酸塩を希塩酸あるいは希硝酸に溶解して調製 し，ポリエチレン瓶に保存した。実験の際には, これらを 適宜希勫して使用した。

$1 \% \mathrm{DMG}$ 溶液は，1.0gの DMG（関東化学）を $1 \%$ 水酸 化ナトリウムで溶解し， $100 \mathrm{~mL}$ とした。

5\% TritonX-100溶液は, $5.0 \mathrm{~g}$ の TritonX-100［オクチル フェノールポリ (エチレングリコールエーテル) $\mathrm{x}$ ，(Fulka]

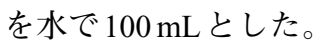

\section{$2 \cdot 2$ 装置と器具}

$\mathrm{Ni}(\mathrm{II})$ および $\mathrm{Fe}(\mathrm{III})$ の測定には Shimadzu AA-6500Fフ レーム原子吸光装置（島津製作所）を用いた。測定条件を
Table 1. Experimental conditions of flame atomic absorption spectrometry.

\begin{tabular}{ll}
\hline Background correction & $\mathrm{D}_{2}$ lamp \\
Gas flow rate & \\
Acetylene & $1.8 \mathrm{~L} / \mathrm{min}$ \\
Air & $15 \mathrm{~L} / \mathrm{min}$ \\
Hollow cathode lamp current & $12 \mathrm{~mA}$ \\
Wavelength & \\
Ni & $232.0 \mathrm{~nm}$ \\
Fe & $248.3 \mathrm{~nm}$ \\
Slit width & $0.2 \mathrm{~nm}$ \\
Burner height & $7 \mathrm{~mm}$ \\
\hline
\end{tabular}

Table 1 に示す。

カラム分離の際は, 内径 $15 \mathrm{~mm}$ のポリプロピレン製カラ ム（エコノパックカラム，バイオ・ラッドラボラトリー ズ）に $0.8 \mathrm{~g}$ の CHP20Pを充てんし（樹脂柱高さ $20 \mathrm{~mm}$ ）， カラム下端にタイゴンチューブとスクリューコックを取り 付けて流速を $1 \mathrm{~mL} \mathrm{~min}{ }^{-1} に$ 調節した。

\section{$2 \cdot 3$ 操作}

\section{$2 \cdot 3 \cdot 1 \quad \mathrm{Fe}(\mathrm{III})$ と $\mathrm{Ni}(\mathrm{II})$ の相互分離}

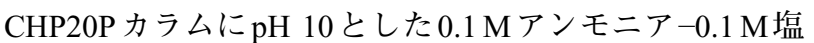
化アンモニウム $-0.05 \%$ TritonX-100溶液 $10 \mathrm{~mL}$ を流してコ ンデショニングした。 $200 \mathrm{mg}$ の Fe(III) と $20 \mu \mathrm{g}$ の Ni(II)を含 む溶液に，最終的に $0.3 \mathrm{M}$ 酒石酸 $-0.05 \% \mathrm{DMG}-0.05 \%$ Triton X-100 となるように各試薬を添加した後，アンモニア で pH10に調整した試料溶液を水で $30 \mathrm{~mL}$ として約 20 分放 置した。この溶液をCHP20Pカラムに負荷し, Ni(II)-DMG 錯体を吸着させた。カラムに吸着していない Fe(III)を除く ため，コンデショニング溶液と同組成の溶液 $20 \mathrm{~mL}$ ，続い て水 $10 \mathrm{~mL}$ でカラムを洗浄した。次いで， $2 \mathrm{M}$ 塩酸 $20 \mathrm{~mL}$ でNi(II)を溶離し, 溶出液をほぼ蒸発乾固した後, $0.1 \mathrm{M}$ 塩 酸で $20 \mathrm{~mL}$ とし，FAASにより測定した。

\section{$2 \cdot 3 \cdot 2$ 鉄鋼認証標準物質中のニッケルの定量}

JSS 519-1（鉛快削鋼，日本鉄鋼連盟）約 $100 \mathrm{mg}$ をはか り取り，(1+1)塩酸 $3 \mathrm{~mL}$, 硝酸 $0.2 \mathrm{~mL}, 30 \%$ 過酸化水素 $0.1 \mathrm{~mL}$ で加熱分解した後, 乾固寸前まで加熱濃縮した。冷 却後, 少量の水を加え, 不溶成分をろ別, $(2+100)$ 温塩酸 でビーカーとろ紙を洗浄した。ろ液と洗液を合わせ，最終 的に $0.1 \mathrm{M}$ 酒石酸 $-0.05 \% \mathrm{DMG}-0.05 \%$ Triton X-100 溶液と なるように各試薬を添加し，アンモニアで $\mathrm{pH} 10$ に調整し てから水で全容を $40 \mathrm{~mL}$ とした。以後，上記と同様にカラ ムに負荷してNiを分離し，FAASにより定量した。なお， ここでは試料量が $100 \mathrm{mg}$ であるため, Fe(III)のマスキング 剤の酒石酸の濃度を $2 \cdot 3 \cdot 1$ 項の場合より低い $0.1 \mathrm{M}$ とした。 


\section{3. 結果と考察}

\section{$3 \cdot 1$ 分離操作の最適化}

\section{$3 \cdot 1 \cdot 1 \quad \mathrm{DMG}$ 濃度}

$20 \mu \mathrm{g}$ の Ni(II)を含む溶液に最終的に $0.75 \%$ TritonX-100$x \% \mathrm{DMG}(x=0.01 \sim 0.15)$ になるように各試薬を添加した後，

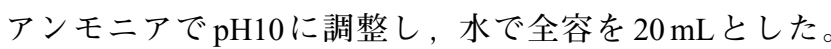
この溶液を $0.8 \mathrm{~g}$ の CHP20Pを詰めたカラムに負荷し， $20 \mathrm{~mL}$ の $1 \mathrm{M}$ 塩酸で溶離し, 回収した NiをFAASにより測 定した。

結果を Fig. 1に示す。 $\mathrm{Ni}$ の回収率は $\mathrm{DMG}$ 濃度の増大と ともに増大し，0.04\%以上でほぼ100\%の回収率となった。 よって，以後の実験では DMG 濃度を $0.05 \%$ とした。なお， 試料溶液調製後, 約 20 分放置してからカラム分離操作を 行うと再現性が向上することが認められた。その理由とし て，20 $\mu \mathrm{g}$ の $\mathrm{Ni}(\mathrm{II})$ が DMG と反応して錯体を形成するため に，この程度の時間を必要とするものと推測される。

$3 \cdot 1 \cdot 2 \mathrm{pH}$

$20 \mu \mathrm{g}$ の Ni(II)を含む溶液に最終的に $0.05 \%$ DMG $-0.75 \%$ TritonX-100になるように各試薬を添加した後, アンモニ アで $\mathrm{pH}$ を調整してから水で $20 \mathrm{~mL}$ の溶液とした。この試 料溶液を $3 \cdot 1 \cdot 1$ 項と同様にカラムに負荷し，回収した $\mathrm{Ni}$ をFAASにより測定した。

その結果, 検討した $\mathrm{pH}$ 範囲 $(8 \sim 11)$ 内でいずれの $\mathrm{pH}$ も定量的な回収を得ることができた。よって, 以後の実験 では，再現性のよかった $\mathrm{pH} 10$ を選択した。

\section{$3 \cdot 1 \cdot 3$ Triton $\mathrm{X}-100$ 濃度}

予備実験の過程で, Ni(II)-DMG 錯体が疎水性樹脂 CHP20Pに強く吸着され，希塩酸により定量的に回収する には大量の溶離液を必要とした（Fig. 2参照)。そこで，塩 酸の使用量を低減させる方法について考察した結果, 試料 溶液に界面活性剤を添加すればCHP20P樹脂表面の吸着力 が弱まり，Ni(II)-DMG 錯体の溶離が容易になるものと推 測するに至り，以下の実験を行った。

まず，界面活性剤として入手しやすいTriton X-100を選 び，その添加濃度の影響について検討した。すなわち， $20 \mu \mathrm{g}$ の Ni(II) を含む溶液の $\mathrm{DMG}$ 濃度を $0.05 \%$ に保ち， $0.001 \sim 0.10 \%$ の濃度になるように必要量の TritonX-100溶 液を添加した後, アンモニアで pH 10 に調整し, 水で全容 を $20 \mathrm{~mL}$ とした。この溶液を $3 \cdot 1 \cdot 1$ 項と同様にカラムに負 荷し，回収したNiをFAASにより測定した。

その結果，Ni(II)の回収率は，Triton X-100濃度が $0.01 \%$ 以下で $100 \%$ をわずに下回ったが，0.025\%以上でほぼ $100 \%$ となっ。よって, 以後の実験では安全をみて 0.05\%を選択した。

ところで, TritonX-100の臨界ミセル濃度は約 $0.016 \%$ で ある ${ }^{11,12)}$ 。本研究では, この臨界ミセル濃度よりもはるか に低い $0.001 \%$ でも Ni(II)がほぼ定量的に回収されている。

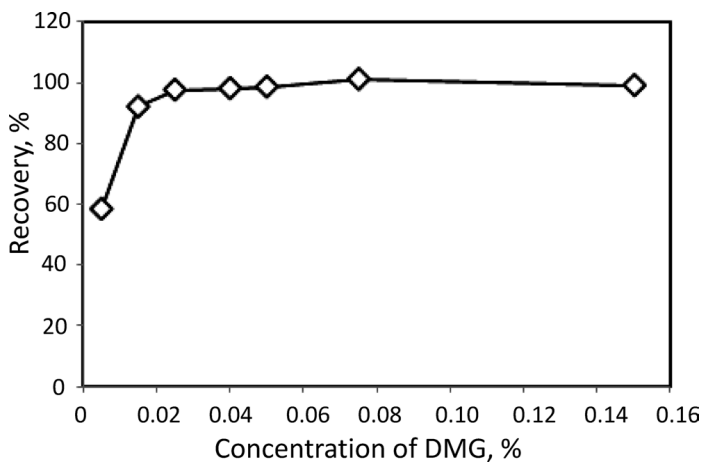

Fig. 1. Effect of dimethylglyoxime (DMG) concentration on the recovery of nickel. Sample solution: $20 \mathrm{~mL}$ of $0.75 \%$ Triton $\mathrm{X}-100-x \%$ DMG solution ( $\mathrm{pH} 10$ ) containing $20 \mu \mathrm{g}$ of $\mathrm{Ni}(\mathrm{II})$. Column: $0.8 \mathrm{~g}$ of MCIGEL CHP20P. Eluent: $20 \mathrm{~mL}$ of $2 \mathrm{M} \mathrm{HCl}$.

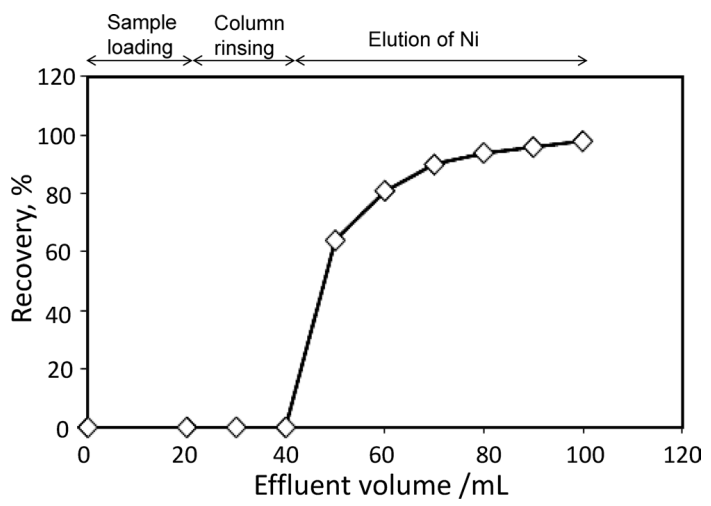

Fig. 2. Elution behavior of nickel adsorbed on the column in the absence of Triton X-100. Sample solution: $20 \mathrm{~mL}$ of $0.05 \%$ DMG solution ( $\mathrm{pH} 10$ ) containing $20 \mu \mathrm{g}$ of $\mathrm{Ni}(\mathrm{II})$. Column: $0.8 \mathrm{~g}$ of MCI-GEL CHP20P. Column rinsing solution: $0.1 \mathrm{M}$ ammonia$0.1 \mathrm{M}$ ammonium chloride solution ( $\mathrm{pH} 10)$. Eluent: $2 \mathrm{M} \mathrm{HCl}$.

したがって，本系ではNi(II)-DMG錯体はTritonX-100のミ セルに取りこまれたのではなく，単にTritonX-100により CHP20P 樹脂への吸着が弱められたものと推論できる。

そこで, カラムにTritonX-100溶液を十分流して CHP20P 樹脂表面を TritonX-100で飽和させてから, 試料溶液にTritonX-100を加えないでカラム操作を行ったところ, Ni(II) は定量的に捕集, 回収できた。このことから，樹脂表面 （細孔を含む）にTritonX-100が吸着し, そのためにNi(II)$\mathrm{DMG}$ 錯体の樹脂への吸着が適度に弱められ，希塩酸によ る定量的回収が達成されたと考えられる。なお，力ラムを TritonX-100で飽和状態にしてから分離操作に用いると， $\mathrm{Ni}(\mathrm{II})$ を含む溶出液にTritonX-100が混入し, 溶出液の蒸発 乾固の際に容器の底に析出して $0.1 \mathrm{M}$ 塩酸による溶解が困 難であった。したがって, 以後の実験では試料溶液にTritonX-100を添加することにした。その際, TritonX-100濃 度を $0.05 \%$ とすると, 少なくとも 10 回連続で分離操作し ても $2 \mathrm{M}$ 塩酸溶出液中にTritonX-100 は認められなかった。 


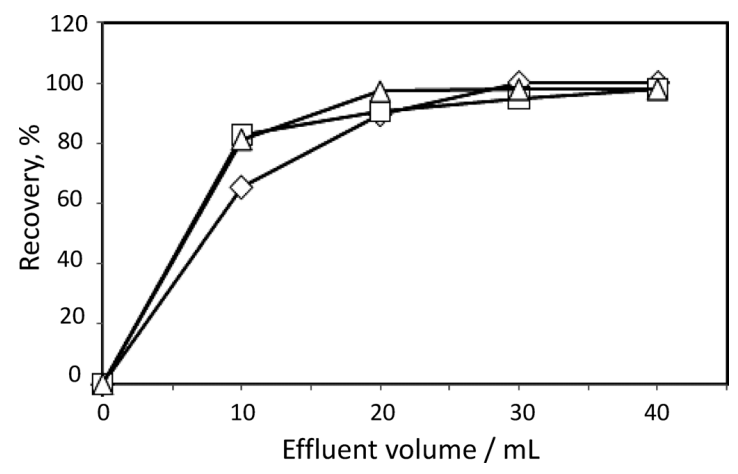

Fig. 3. Effect of the amount of MCI-GEL CHP20P resin packed in the column on the recovery of nickel. Amount of resin: $\triangle, 0.5 \mathrm{~g} ; \square, 0.8 \mathrm{~g} ; \diamond, 1.0 \mathrm{~g}$. Sample solution: $20 \mathrm{~mL}$ of $0.05 \% \mathrm{DMG}-0.05 \%$ Triton $\mathrm{X}-100$ (pH 10) containing $20 \mu \mathrm{g}$ of Ni(II). Column: $x \mathrm{~g}$ of MCI-GEL CHP20P. Eluent: $2 \mathrm{M} \mathrm{HCl}$.

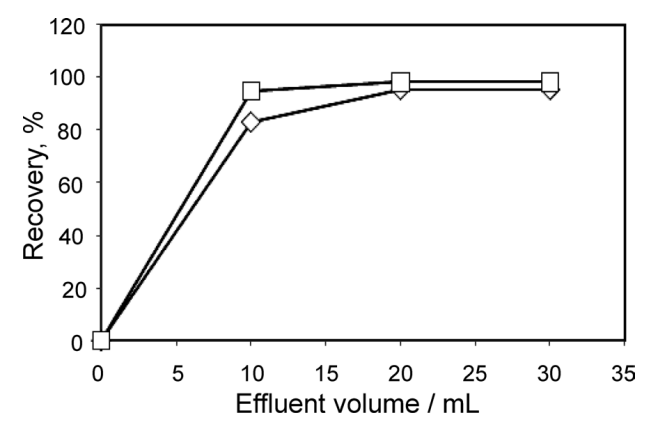

Fig. 4. Effect of the hydrochloric acid concentration as an eluent on the elution of nickel. Sample solution: $20 \mathrm{~mL}$ of $0.05 \%$ DMG $-0.05 \%$ Triton X-100 (pH 10) containing $20 \mu \mathrm{g}$ of $\mathrm{Ni}(\mathrm{II})$. Column: $0.8 \mathrm{~g}$ of MCI-GEL CHP20P. Column rinsing solution: $0.1 \mathrm{M}$ ammonia-0.1 M ammonium chloride solution $(\mathrm{pH} 10)$. Eluent: $1 \mathrm{M}(\diamond)$ or $2 \mathrm{M}(\square) \mathrm{HCl}$.

\section{$3 \cdot 1 \cdot 4$ 樹脂量}

$20 \mu \mathrm{g}$ の Ni(II) を含む溶液に最終的に $0.05 \%$ DMG- $0.05 \%$ TritonX-100になるように各試薬を添加した後, アンモニ

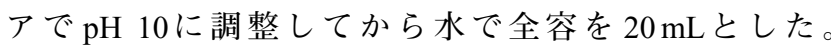
CHP20Pの量の異なる各カラムに試料溶液を $3 \cdot 1 \cdot 1$ 項と同 様に負荷し，溶離した Ni(II)をFAASにより測定した。

結果を Fig. 3 に示す。樹脂量が $0.5 \mathrm{~g}$ (内径 $15 \mathrm{~mm}$, 樹脂 高さ $13 \mathrm{~mm}$ ) では, 溶離液量は少なくてすむが, 再現性が 若干低下した。一方, 樹脂量が $1.0 \mathrm{~g}$ (内径 $15 \mathrm{~mm}$, 樹脂高 さ $26 \mathrm{~mm})$ では, 再現性は良好であったが, 溶離液量が増 え，FAAS 測定前の蒸発乾固の時間が長くなる不都合が あった。したがって, 溶離液量が適量で再現性が良好で あった中間の $0.8 \mathrm{~g}$ （内径 $15 \mathrm{~mm}$, 樹脂高 $20 \mathrm{~mm}$ ）を以後の 実験に採用した。

\section{$3 \cdot 1 \cdot 5$ 溶離液}

溶離液として塩酸を用い, その濃度の影響を調べた。結 果をFig. 4 に示す。1 Mでは溶離に要する液量が増えるの で，溶離液体積が $20 \mathrm{~mL}$ ですむ $2 \mathrm{M}$ を選択した。

なお, 溶出液をそのままFAASに供するよりも, 溶出液

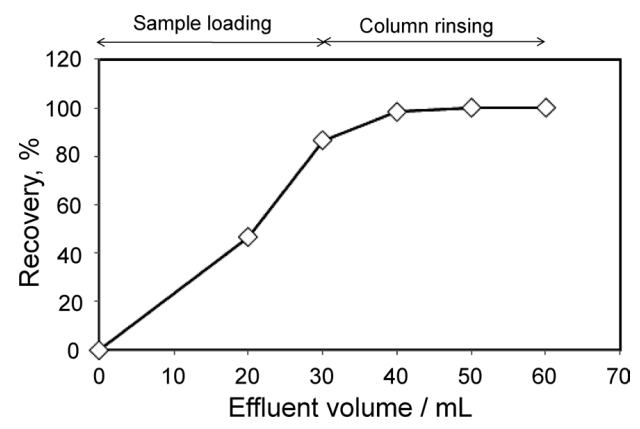

Fig. 5. Elution behavior of iron. Sample solution: $30 \mathrm{~mL}$ of $0.3 \mathrm{M}$ tartaric acid- $0.05 \%$ DMG- $0.05 \%$ Triton X-100 (pH10) containing $200 \mathrm{mg}$ of $\mathrm{Fe}(\mathrm{III})$. Column: $0.8 \mathrm{~g}$ of MCI-GEL CHP20P. Column rinsing solution: $0.1 \mathrm{M}$ ammonia-0.1 $\mathrm{M}$ ammonium chloride solution $(\mathrm{pH} \mathrm{10)}$.

をホットプレート上でほぼ蒸発乾固した後に $0.1 \mathrm{M}$ 塩酸に

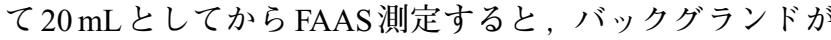
低下した。このバックグランド低下の理由は不明であるが， 溶出液は $0.1 \mathrm{M}$ 塩酸溶液として FAAS 測定に供することに した。

\section{$3 \cdot 2 \mathrm{Fe}(\mathrm{III})$ の溶出挙動}

以上の最適条件下で, $\mathrm{Fe}(\mathrm{III})$ のみを含む試料溶液をカラ ムに負荷し，その溶出挙動を調べた。すなわち， $200 \mathrm{mg}$ の $\mathrm{Fe}(\mathrm{III})$ を含む溶液に, 最終的に $0.3 \mathrm{M}$ 酒石酸 $-0.05 \% \mathrm{Tri}-$ tonX-100-0.05\% DMG 溶液となるよう各試薬を添加し，ア ンモニアで $\mathrm{pH} 10$ に調整し $30 \mathrm{~mL}$ とした。この溶液をコン デショニングずみの CHP20Pカラムに負荷した。Fe(III)は カラムに吸着しないので， $20 \mathrm{~mL}$ の $0.1 \mathrm{M}$ アンモニア$0.1 \mathrm{M}$ 塩化アンモニウム溶液 $(\mathrm{pH} \mathrm{10}$ ) と $20 \mathrm{~mL}$ の水で $200 \mathrm{mg}$ の Fe(III)を定量的に回収することができた（Fig. 5参照）。

なお，アンモニア性溶液によるカラム洗浄に続いて塩酸 溶液を通液すると, カラム内で塩基・酸の混合が生じ, $\mathrm{Ni}(\mathrm{II})$ の溶離の初期段階で効率が悪くなる。そのため, 溶 離前に $10 \mathrm{~mL}$ の水を流してから $2 \mathrm{M}$ 塩酸溶液を流すことに した。

\section{$3 \cdot 3 \mathrm{Fe}(\mathrm{III})$ と $\mathrm{Ni}(\mathrm{II})$ の相互分離}

$3 \cdot 1$ 節の最適化条件下で, $\mathrm{Fe}(\mathrm{III})$ と $\mathrm{Ni}(\mathrm{II})$ との混合溶液 をカラムに負荷し, 両者の溶出挙動を調べた。結果を Fig. 6 に示す。 Fe(III) は試料溶液負荷およびカラム洗浄の段階 で定量的に回収でき，Ni(II)は溶離開始以前には流出しな

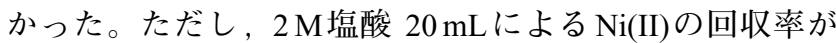
約 $110 \%$ となった。これは高濃度の鉄標準溶液中に不純物 として微量の Niが含まれていたためと推察した。このこ とを明らかにするためにNiを含まない鉄のみの試料溶液 を用いて一連の操作を行った。結果を Table 2 に示す。予 想通り, 試薬ブランク值を補正すれば, Niが Feから定量 的に分離されていることがわかる。

\section{$3 \cdot 4$ 共存元素の影響}

鉄鋼に添加されていることの多い金属の影響を調べ，結 


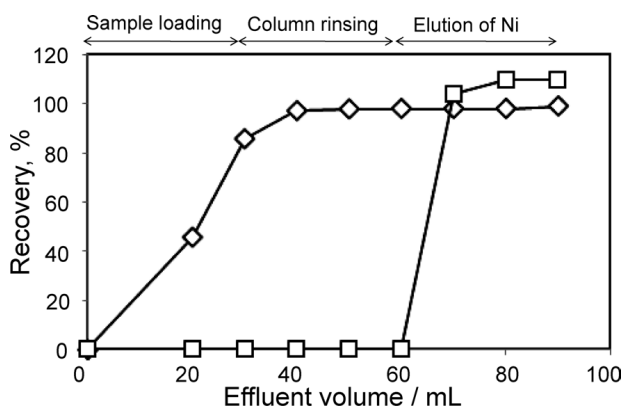

Fig. 6. Elution behavior of iron and nickel. Sample solution: $30 \mathrm{~mL}$ of $0.3 \mathrm{M}$ tartaric acid- $0.05 \%$ DMG- $0.05 \%$ Triton $\mathrm{X}-100(\mathrm{pH} 10)$ containing $200 \mathrm{mg}$ of $\mathrm{Fe}(\mathrm{III})$ and $20 \mu \mathrm{g}$ of Ni(II). Column: $0.8 \mathrm{~g}$ of MCI-GEL CHP20P. Column rinsing solution: $20 \mathrm{~mL}$ of $0.1 \mathrm{M}$ ammonia- $0.1 \mathrm{M}$ ammonium chloride solution and then $10 \mathrm{~mL}$ of water. Eluent: $2 \mathrm{M} \mathrm{HCl} . \diamond, \mathrm{Fe}(\mathrm{III}) ; \square, \mathrm{Ni}(\mathrm{II})$.

Table 2. Mutual separation of iron and nickel*.

\begin{tabular}{llll}
\hline Run & Metal & Added / $\mu \mathrm{g}$ & Found $/ \mu \mathrm{g}$ \\
\hline 1 & $\mathrm{Fe}(\mathrm{III})$ & $2.00 \times 10^{5}$ & $1.99 \times 10^{5}$ \\
& $\mathrm{Ni}(\mathrm{II})$ & 0 & $2.0_{6}$ \\
2 & $\mathrm{Fe}(\mathrm{III})$ & $2.00 \times 10^{5}$ & $1.97 \times 10^{5}$ \\
& $\mathrm{Ni}(\mathrm{II})$ & 20.0 & 22.04 \\
\hline
\end{tabular}

* In $30 \mathrm{~mL}$ solution of $0.3 \mathrm{M}$ tartaric acid- $0.05 \% \mathrm{DMG}-$ $0.05 \%$ Triton X-100.

Table 3. Effect of foreign ions.

\begin{tabular}{cl}
\hline Ion & Maximum tolerance* \\
\hline $\mathrm{Al}(\mathrm{III})$ & 100 \\
$\mathrm{Cu}(\mathrm{II})$ & 100 \\
$\mathrm{Mn}(\mathrm{II})$ & 100 \\
$\mathrm{Sn}(\mathrm{IV})$ & 100 \\
$\mathrm{Ti}(\mathrm{IV})$ & 100 \\
$\mathrm{Mg}(\mathrm{II})$ & 50 \\
$\mathrm{~Pb}(\mathrm{II})$ & 50 \\
$\mathrm{Co}(\mathrm{II})$ & 25 \\
$\mathrm{Cr}(\mathrm{VI})$ & 25 \\
$\mathrm{Pd}(\mathrm{II})$ & 25 \\
\hline Mass ratio at which the relative error is less than \\
5 \% when 20 pg of Ni(II) is determined.
\end{tabular}

果をTable 3に示す。Ni(II) 1 ppmに対して，少なくともこ こに示した割合の金属を添加しても，Niの回収率に対し て 5\%以上の影響を与えなかった。 $\mathrm{Co}(\mathrm{II}), \mathrm{Cr}(\mathrm{VI})$ および $\mathrm{Pd}(\mathrm{II})$ に関しては 50 倍存在すると回収率が $5 \%$ 以上低下し た。Co(II)と Pd(II)については，DMGと反応して DMGを 消費して $\mathrm{Ni}(\mathrm{II})-\mathrm{DMG}$ 錯体の生成を妨げるためと考えられ る ${ }^{13)}$ 。また, 多量の $\mathrm{Cr}(\mathrm{VI})$ は $\mathrm{DMG}$ を酸化し，その濃度を
Table 4. Determination of nickel in synthetic mixtures*.

\begin{tabular}{cc}
\hline Ni added $/ \mu \mathrm{g}$ & Ni found $* * / \mu \mathrm{g}$ \\
\hline 0 & $1.9 \pm 0.1$ \\
20.0 & $21.5 \pm 0.4$ \\
\hline
\end{tabular}

* Fe $2.00 \times 10^{5} \mu \mathrm{g}, \mathrm{Mn} 450 \mu \mathrm{g}$, and $\mathrm{Cr} 390 \mu \mathrm{g}$ in $20 \mathrm{~mL}$ of $0.3 \mathrm{M}$ tartaric acid $-0.05 \% \mathrm{DMG}-0.05 \%$ Triton X-100 (pH 10).

**average \pm S.D. $(n=3)$.

Table 5. Determination of nickel in certified reference material*.

\begin{tabular}{|c|c|c|}
\hline Sample taken /g & Found / $\mu \mathrm{g} \mathrm{g}^{-1}$ & Certified / $\mu \mathrm{g} \mathrm{g}^{-1}$ \\
\hline $0.1027 \pm 0.0011^{* *}$ & $558 \pm 6^{* *}$ & 560 \\
\hline \multicolumn{3}{|c|}{ * JSS 519-1(lead free-cutting steel) provided by Japan Iron and Steel } \\
\hline \multicolumn{3}{|c|}{ Federation. C $0.390 \%$; Si $0.250 \%$; Mn $0.700 \%$; P $0.012 \%$; Cr $0.120 \%$} \\
\hline \multicolumn{3}{|l|}{$\mathrm{Cu} 0.105 ; \mathrm{Pb} 0.097 \%$} \\
\hline$* *$ average \pm S.D. $(n=$ & & \\
\hline
\end{tabular}

低下させるためであると推測した。

\section{$3 \cdot 5$ 鉄鋼模擬試料を用いた $\mathrm{Ni}(I I)$ の分離定量}

鉄鋼標準認証物質 JSS 519-1（鉛快削鋼）の認証值にも とづき, 含有率 $1 \%$ 以上の元素で模擬試料を調製し, Ni(II) の分離を試みた。すなわち, $200 \mathrm{mg} \mathrm{Fe}(\mathrm{III}), 20 \mu \mathrm{gNi}(\mathrm{II})$, $450 \mu \mathrm{g} \mathrm{Mn}(\mathrm{II}), 390 \mu \mathrm{g} \mathrm{Cr}(\mathrm{VI})$ を含む溶液に, 最終的に $0.3 \mathrm{M}$ 酒石酸- $0.05 \%$ DMG- $0.05 \%$ Triton X-100 となるように各試 薬を添加した後, アンモニア水で $\mathrm{pH} 10$ に調整し模擬試料 溶液 $20 \mathrm{~mL}$ とした。得られた結果を Table 4 に示す。Fe(III), $\mathrm{Mn}(\mathrm{II}), \mathrm{Cr}(\mathrm{III} / \mathrm{VI})$ は洗浄段階までに定量的に回収でき， $\mathrm{Ni}(\mathrm{II})$ は溶離開始以前には流出しなかった。この場合も， $2 \mathrm{M}$ 塩酸 $20 \mathrm{~mL}$ による $\mathrm{Ni}(\mathrm{II})$ の回収率が約 $110 \%$ となった。 これも $3 \cdot 3$ 節と同様の理由であって, 試薬ブランク值を補 正すれば定量的な結果が得られていることがわかる。

\section{$3 \cdot 6$ 鉄鋼認証標準物質中の $\mathrm{Ni}$ の定量}

以上の結果にもとづき, 鉄鋼認証標準物質 JSS519-1（鉛 快削鋼）中の $\mathrm{Ni}$ の定量を行った。結果を Table 5 に示す。 定量値は認証值とよく一致し, 相対標準偏差 $1.1 \%(n=3)$ と再現性も良好であった。

\section{4. 結言}

$\mathrm{Ni}$ ⿸ DMG 錯体として選択的に固相抽出する際，非イオ ン界面活性剤の TritonX-100を添加することによって Niの 定量的溶離を達成した。さらに，本法を $\mathrm{Fe}$ と $\mathrm{Ni}$ の相互分 離に拡張し, FAASによる $\mathrm{Ni}$ の測定を組み合わせ, 鉄鋼標 準認証物質 JSS 519-1（鉛快削鋼）中の Niの定量に成功し た。

本法は，Niに高選択的な DMGを錯生成試薬に用いるも 
ので，鉄鋼のみならず，さまざまな合金中の $\mathrm{Ni}$ の定量に 適用可能と期待される。また，有機溶媒を用いないことか ら環境負荷が小さく，環境調和型分析技術として優れてい る。

\section{文献}

1 ) Bull. Iron Steel Inst. Jpn., 10 (2005), 906.

2 ) 分析化学便覧改訂 3 版, 日本分析化学会編, 丸善, 東京, (1981), 669.

3 ) T.R.Dulski: Trace Elemental Analysis of Metals, Marcel Dekker, New York, (1999), 53.
4 ) 石橋耀一：化学分析・試験に役立つ標準物質活用ガイド，久 保田正明編著，丸善，(2009), 131.

5 ) JIS G 1257-1994鉄及び鋼一原子吸光分析方法.

6 ) JIS G 1216-1997鉄及び鋼ーニッケル定量方法.

7 ) V.Camel: Spectrochim. Acta, B58 (2003), 1177.

8 ) A.Ali, Y.Ye, G.Xu, X.Yin and T.Zhang: Michrochem. J., 63 (1999), 365.

9 ) F.Shemirani, M.Zamani and M.R.Jamali: Iran. J. Chem. Chem. Eng., 22 (2003), 55.

10) http://www.eichrom.com/products/

11) A.Helenius and K.Simons: Biochim. Biophys. Acta, 415 (1975), 29.

12) S.C.Goheen and R.S.Matson: J. Am. Oil Chem. Soc., 66 (1989), 994.

13) F.Feigl and V.Anger: Spot Tests in Inorganic Analysis, Elsevier, Amsterdam, (1972), 325. 